How Central Should the Central Bank Be?

by

Alan S. Blinder, Princeton University

CEPS Working Paper No. 198

January 2010 


\title{
How Central Should the Central Bank Be?*
}

\author{
Alan S. Blinder \\ Princeton University
}

January 2010

About six years ago, I published a small book entitled The Quiet Revolution (Blinder 2004). Though its subtitle was “Central Banking Goes Modern,” I never imagined the half of it. Since March 2008, the Federal Reserve has gone post-modern with a bewildering variety of unprecedented actions that have either changed the nature and scope of the central bank's role or stretched it beyond the breaking point, depending on your point of view. And that leads straight to the central question of this essay: What should--and shouldn't--the Federal Reserve do?

The question is not purely intellectual, for America is now debating whether to broaden its central bank's wings or to clip them. As I write this in January 2010, Congress and the administration are arguing over whether the Federal Reserve’s roles in financial regulation, bank supervision, consumer protection, and the preservation of financial stability should be enhanced, limited, or even eliminated. There is even discussion of whether it has too much independence in the sphere of monetary policy. As a result, the nature and scope of the Federal Reserve's authority and the structure of its decision-making are now "on the table" to an extent that has not been seen since 1935, when the Federal Reserve Act last had a major overhaul.

\footnotetext{
${ }^{*}$ Prepared for the Journal of Economic Literature. This is a statement of personal views, but I have benefited from innumerable discussions of these issues over the years with many knowledgeable people in academia, government, and the financial markets. I thank them all. I also gratefully acknowledge financial support for my research on central banking from Princeton’s Center for Economic Policy Studies.
} 
In addressing this set of questions, I will lean heavily on the concept of economies of scope. My approach starts with a simple and, I think, uncontroversial premise: that monetary policy proper, by which I mean the manipulation of interest rates and bank reserves to steer aggregate demand in the desired direction, should be conducted by an independent central bank. ${ }^{1}$ I will neither elucidate nor defend the arguments for central bank independence here. To economists, at least, that debate ended long ago. Instead, taking central bank independence over monetary policy as given, I will pose and attempt to answer two main questions: What sorts of instruments (other than the overnight rate) must a central bank control in order to do its job most effectively? What other powers are "so closely related to" monetary policy "as to be a proper incident thereto"? ${ }^{2}$

\section{The Four Traditional Roles of a Central Bank}

Ever since Keynes, central banks have played four traditional roles:

1. conducting monetary policy, including the possible use of lender-of-last-resort (LOLR) powers in that regard. Prior to the Keynesian revolution, of course, central banks were not thinking about monetary policy. But they did perform the other three roles.

2. preserving financial stability or, in the older jargon, preventing and/or mitigating panics. In serving this classic role, LOLR powers are almost always invoked.

\footnotetext{
${ }^{1}$ This characterization of monetary policy is deliberately broader than so-called narrow inflation targeting; it explicitly allows for the Fed's dual mandate. It is fully consistent, however, with so-called flexible inflation targeting. See, for example, Lars Svensson (1999), pp. 200-202.

${ }^{2}$ The quoted words are part of Federal Reserve regulatory jargon. According to Section 4(c)(8) of the Bank Holding Company Act, bank holding companies are permitted to engage in non-banking activities that are "so closely related to banking as to be a proper incident thereto." The interpretation of that phrase has always been controversial.
} 
3. supervising and regulating banks. Here, however, there has been a recent (and partial) trend away from having bank supervision done inside the central bank. Several countries have, instead, placed regulatory authority in separate agencies outside the central bank. In the United States, of course, the Fed has long been just one of four federal banking agencies. ${ }^{3}$

4. safeguarding payment and settlement systems, which might or might not mean actually operating them. Here, again, LOLR powers are likely to be used on occasion—as the Fed demonstrated dramatically right after 9/11.

You will have noticed three distinct references to LOLR authority in the preceding list of four functions. The ability to serve as lender of last resort may be the defining power of the central bank — the unique ability that no one else has. Indeed, in extreme cases (e.g., "bailouts”), the LOLR role can even become part of bank supervision. In what follows, I mostly ignore payments system issues and concentrate on the other three.

\section{Monetary Policy Proper}

While there is plenty of squabbling over details, there is not much debate these days about the role of the central bank in deciding upon and implementing monetary policy. In most countries, the central bank is given 100 percent of the job, with minimal or no outside interference. Still, at least three questions are on the table in the U.S. today. First, should the Fed be more accountable to Congress than it is at present—-such as provided for in the Paul bill? ${ }^{4}$ Second, is it appropriate that monetary policy decisions be made by

\footnotetext{
${ }^{3}$ The other three are the Office of the Controller of the Currency (OCC), the Federal Deposit Insurance Corporation (FDIC), and the Office of Thrift Supervision (OTS). Each state also has bank regulatory agencies.

${ }^{4}$ The bill, named after Congressman Ron Paul (R-TX), would subject the FOMC's monetary policy decisions to audit by the Government Accountability Office (GAO). It was modified and incorporated into the financial reform bill that passed the House in December 2009.
} 
the 19 office-holders who presently constitute the Federal Open Market Committee (FOMC), only seven of whom are politically appointed? ${ }^{5}$ Third, should bursting or "leaning against” asset-price bubbles be an integral part of monetary policy? I take up each question in turn, albeit briefly.

\subsection{Monetary Policy Independence and the Paul Bill}

In the United States, central bank independence (CBI) to conduct monetary policy is more a matter of tradition than of law. ${ }^{6}$ Scour the Constitution, and you will find no mention of a central bank, much less of CBI. ${ }^{7}$ Rather, the Federal Reserve was created by an ordinary act of Congress in 1913. Legislators can change that law any day, and in any way, they choose—including abolishing the Fed entirely, which is precisely what Congress did to the First and Second Banks of the United States. Nor is there any question that Congress has both the right and the duty to oversee the Fed's operations, which it does through periodic hearings and in other ways. Yet Fed Chairman Ben Bernanke has characterized the Paul bill as something that would "increase the perceived influence of Congress on monetary policy." ${ }^{8}$ What's the issue here?

The Paul bill started as a piece of free-standing legislation that would end the exemption from audit that now applies to the Fed's monetary policy and dealings with foreign central banks and governments. (Everything else is auditable now.) The bill was short, to the point and, in the eyes of many economists, a serious threat to the Fed's independence. But when it was attached to the House version of financial reform

\footnotetext{
${ }^{5}$ Although only 12 FOMC members vote at any given meeting, all 19 participate. These are the seven members of the Board of Governors in Washington and the 12 presidents of the district Reserve Banks.

${ }^{6}$ Furthermore, people often forget that Federal Reserve "independence" has always been restricted to monetary policy, not, e.g., to bank supervision and regulation.

${ }^{7}$ Instead, Article I, Section 8 assigns to Congress the power "to coin Money [and] regulate the Value thereof."

${ }^{8}$ See Bernanke (2009).
} 
legislation, the bill was amended in two important ways that seem barely to have been noticed. $^{9}$

First, the text now states that GAO audits "shall not include unreleased transcripts or minutes of meetings of the Board of Governors or the Federal Open Market Committee.” That important exclusion enhances both confidentiality and the independence of monetary policy. But it’s not quite enough because of a legalism. Non-lawyers might naturally assume that the words quoted above implicitly instruct the GAO not to ask Fed officials to reveal information about those confidential documents. After all, what sense does it make to rule the documents out of bounds but allow the GAO to request information about their contents? Apparently, however, there is no such implication in U.S. law. So, for example, the current statute (USC 31, Subtitle I, Chapter 7, Subchapter 2, Section 714.4) provides this “obvious” extension explicitly—in words that can and should be imported directly into Paul-Grayson. ${ }^{10}$

Second, and even more important, a clause was added stating that, "Nothing in this subsection shall be construed as interference in or dictation of monetary policy to the Federal Reserve System by the Congress or the Government Accountability Office.” My first reaction, upon reading this, was: “Wow. That's the strongest affirmation of monetary policy independence that exists anywhere in U.S. law.” But a slower, lawyerly parsing of the words leads to a different conclusion. Read literally, the sentence simply asserts that Paul-Grayson is not an "interference in or dictation of monetary policy.” Oh, really? Lots

\footnotetext{
9 It became the Paul-Grayson amendment, which became Section 1254(c) of H.R. 4173, "The Wall Street Reform and Consumer Protection Act of 2009.”

${ }^{10}$ Current law states that "Audits of the Federal Reserve Board and Federal Reserve banks may not include ... (4) a part of a discussion or communication among or between members of the Board of Governors and officers and employees of the Federal Reserve System related to clauses (1)-(3) of this subsection.” The ellipses connote the three clauses I have omitted from the quotation. They list the three items that are placed outside the scope of GAO audits.
} 
of people construe it that way. Fortunately, this legalistic attempt at thought control can be eliminated by inserting a single gerund into the relevant sentence. For example, if Congress rewrote it as, "Nothing in this subsection shall be construed as allowing interference in or dictation of monetary policy...," the clause would say what a plainEnglish reading suggests.

Why, then, do the Fed and many economists still view Paul-Grayson with alarm? One reason is that neither of these two "minor" changes have been made. They should be. But I think the main reason is the justifiable concern that, once a camel's nose gets under the tent, the rest of the camel will try to follow. It has not escaped anyone's notice that Congressman Paul's latest book (Ron Paul 2009) is entitled, End the Fed. We know where this particular camel wants to go, and most economists do not want it to get there. ${ }^{11}$ Congress should not either, because mountains of empirical evidence support the proposition that greater CBI produces not only less inflation but superior macroeconomic performance, e.g., lower and less volatile inflation with no more volatility in output. ${ }^{12}$

Despite that, the Paul bill garnered the support of more than two-thirds of the House of Representatives even before it was amended to make it more palatable in the ways just discussed. In a political environment in which regard for the Fed has hit rock bottom, ${ }^{13}$ economists' technical arguments have not been very persuasive, leaving the independence of the Fed under some threat.

\footnotetext{
${ }^{11}$ For example, my surveys (see Blinder 2000) found that both central bankers and economists rated central bank independence as the second most important (out of seven) ways to establish or maintain credibility. A petition against the Paul bill, circulated in November 2009, rapidly garnered the signatures of over 300 economists. It can be found at:

https://survey.chicagobooth.edu/ViewsFlash/servlet/viewsflash?cmd=showform\&pollid=gfm!fedpetition2.

${ }^{12}$ For a recent summary, see Daron Acemoglu et al. 2008.

${ }^{13}$ To cite just one example, a July 2009 Gallup poll found that the public judges the Fed to have done the worst job among nine federal agencies tested--a list that included Homeland Security, the CIA, and the IRS!
} 


\subsection{The Structure of the FOMC}

There was no FOMC when the Federal Reserve System opened for business in 1914. Even Keynes was busy thinking about wartime finance, not about discretionary monetary policy. The FOMC officially traces its origins to amendments to the Federal Reserve Act in the 1930s, and today's committee reflects the founders' original desire to balance power between government officials in Washington, who might be "political," and bankers, who are presumably reliable stalwarts against inflation.

The 12 district banks are, technically, private corporations with shareholders and boards of directors. ${ }^{14}$ As shareholders, bankers select or are influential in selecting six of the nine members of each Reserve Bank board—none of whom are political appointees. And each of these boards, in turn, essentially selects the president of its bank, who sits on the FOMC as a national policymaker. ${ }^{15}$ This is a highly unusual way to select policymakers, to say the least. The president of the Federal Reserve Bank of New York is much more than just a member of the FOMC. He serves as the committee's vice chairman, has a vote at every meeting (while the other bank presidents rotate), often represents the Fed in international forums (e.g., in Basel), and is often the point man in a financial crisis or near-crisis. Yet, unlike Fed governors, none of the Reserve Bank presidents have the democratic legitimacy that is conferred by political appointment.

Arrangements like this are presumably what led populist Congressman Wright Patman (D-TX) to declare many years ago that, "A slight acquaintance with American constitutional theory and practice demonstrates that, constitutionally, the Federal Reserve

\footnotetext{
${ }^{14}$ A revealing curiosity: Each Federal Reserve Bank is a “dot.org,” while only the Board of Governors in Washington is a "dot.gov."

15 Their selections must be approved by the Board of Governors, which virtually always does so.
} 
is a pretty queer duck." ${ }^{16}$ It is hard to dispute Patman's proposition in the abstract. Who, writing on a blank slate today, would design such a structure? In fact, the best (only) defense of the FOMC's odd power structure may be to claim—with some justification— that it has worked well for 75 years. So why change it now?

Many changes in FOMC governance have been proposed over the years, including: removing the Reserve Bank presidents from the FOMC, leaving them on the FOMC but making them political appointees, making just the president of the New York Fed a political appointee, and making the chairs of each of the 12 district boards of directors political appointees. To date, none have been adopted. But Senator Christopher Dodd (DCT), the chairman of the Senate Banking Committee, has recently advocated the latter. Each such suggestion needs to be confronted with the question posed in the previous paragraph: Would it lead to better policy decisions?

\subsection{Asset Bubbles and Monetary Policy}

The next question is whether bursting, or even "leaning against," asset-price bubbles should be an integral part of monetary policy. Or should the Federal Reserve eschew second-guessing market valuations and content itself with “mopping up” after bubbles burst? I will call the latter the Greenspan-Bernanke approach, since the last two Fed chairmen have embraced it. ${ }^{17}$ But truth-in-writing demands that I confess to have advocated the "mop-up-after” approach, too. ${ }^{18}$

This is not the place for a thorough discussion of the pros and cons of bubble bursting; I have offered that elsewhere (Blinder and Ricardo Reis 2005, Blinder 2006,

\footnotetext{
${ }^{16}$ Quoted in William Greider (1987), p. 49. The quotation is from 1964.

${ }^{17}$ See, for example, Alan Greenspan (2002) and Ben Bernanke (2002). More recently, Chairman Bernanke seems to have backed off this position just a bit; see the closing section of Bernanke (2010).

${ }^{18}$ Cf. Blinder and Reis (2005), pp. 64-70.
} 
2008), as have others. But Frederic Mishkin (2008) and Blinder (2008) have argued that a distinction should be drawn between credit-fueled bubbles (such as the house price bubble) and equity-type bubbles in which credit plays only a minor role (such as the 1998-2000 tech-stock bubble). In their view, the mop-up-after approach is still appropriate for equity bubbles not fueled by borrowing, but the central bank should try to limit credit-based bubbles — though probably more with regulatory instruments than with interest rates. This attitude may eventually become the new consensus on how to deal with asset-pricebubbles; indeed, Bernanke (2010) comes close to endorsing it. But we are not there yet.

In any case, it is worth noting for future reference (see the next section) that the strongest argument against the Greenspan-Bernanke view is a financial stability argument: When bubbles inflate and subsequently burst, they threaten financial stability which, in turn, undermines the Fed's ability to pursue its standard macroeconomic goals, low inflation and high employment.

This discussion of monetary policy sets the stage for the rest of the paper. Taking it as axiomatic that pursuing an independent monetary policy is the essence of the Fed's business, I now turn to the economies-of-scope question: Does that imply that the Fed should also be a bank supervisor and/or what has come to be called the systemic risk regulator?

\section{Systemic Risk Regulation}

I interpret the phrases "regulating systemic risk" and "guarding against financial instability” as nearly synonymous. However, neither has a crisp, clear definition; each invites instead a "you know it when you see it" attitude. In some formal models of 
monetary policy, financial stability is identified with a low variance of interest rates. For example, putting $\operatorname{var}\left(\mathrm{r}_{\mathrm{t}}\right)$, rationalized as an indicator of financial instability, into the central bank's loss function is a commonly-used device to get $\mathrm{r}_{\mathrm{t}-1}$ included in empirical monetary policy reaction functions. ${ }^{19}$ But that focus seems far too narrow, not to mention too formulaic.

I propose defining a systemic risk as one that is either large enough in size or broad enough in scope that, if things go wrong, it can damage a significant portion of the financial system. The definition is clearly subjective and not numerical. Thus, a handful of truly gigantic financial institutions are probably large enough to constitute systemic risks all by themselves. Those are the systemically important financial institutions (SIFIs) that are too big to be allowed to fail messily. Other, much smaller firms can pose systemic risks only if many of them act in the same way at the same time. ${ }^{20}$ Finally, some firms are so intertwined with others that their failure could pose systemic risks out of proportion to their size. ${ }^{21}$ One case in point is firms that are essential to the payment and settlement system. For example, NYSE Euronext is not a very large firm, but its disorderly failure would be intolerable.

The recent financial disruptions laid bare a major regulatory lacuna: the absence of a single agency responsible for preserving financial stability--the so-called systemic risk regulator (SRR). One possible reaction to this claim is: "Wait a minute. Isn’t the Fed already the systemic risk regulator in the U.S.?” My answer to this question is: almost, but not quite. Yes, the Fed is the SRR, but only tacitly, not explicitly. In consequence, it

\footnotetext{
${ }^{19}$ See, among many others, Glenn Rudebusch (2002).

${ }^{20}$ Some examples: dozens of hedge funds with big positions in the same trade, thousands of banks making subprime mortgages with disgraceful underwriting standards.

${ }^{21}$ Some examples: Bear Stearns in March 2008, Lehman Brothers and AIG in September 2008, though AIG may have qualified on the size criterion alone.
} 
probably lacks some of the tools and powers it needs to do the job properly — not to mention the mission focus and the explicit responsibility.

In my view, the Fed should be made the (explicit) SRR for a variety of reasons. The first is a straightforward argument based on economies of scope. Figure 1 depicts a regulatory continuum ranging from the most "macro" function, monetary policy, on the left, to the most "micro" function, the prudential supervision of small banks, on the right. In between come two intermediate functions: preserving financial stability (which is often called “macro-prudential”), and the “micro-prudential” supervision of large institutions, especially the SIFIs.

Figure 1

\begin{tabular}{ll|cc} 
& 1 & 2 & 3 \\
\hline $\begin{array}{l}\text { monetary } \\
\text { policy }\end{array}$ & $\begin{array}{l}\text { financial } \\
\text { stability }\end{array}$ & $\begin{array}{c}\text { supervision \& regulation } \\
\text { of SIFIs }\end{array}$ & $\begin{array}{c}\text { supervision \& regulation } \\
\text { of small institutions }\end{array}$ \\
more macro & & & \\
more micro
\end{tabular}

Everyone agrees that monetary policy should be the sole preserve of the central bank. But where, after that, do you draw the line? Some people would draw it right there, at point 1 in the figure, by assigning systemic risk regulation to some other body, such as the Treasury’s proposed Financial Services Oversight Council (FSOC). ${ }^{22}$ To me, such a separation of functions ignores obvious and probably strong economies of scope.

Financial stability is so closely related to the standard goals of monetary policy (stabilizing output and inflation) that it is “a proper incident thereto.” It therefore seems somewhere between foolish and impossible to separate the two functions.

${ }^{22}$ See U.S. Treasury (2009), Section I.A. 
Furthermore, the pursuit of financial stability will often involve using lender-of-lastresort powers. For these reasons, central banks all over the world (including the U.S.) have naturally assumed responsibility for financial stability, albeit not always with great success. ${ }^{23}$ Finally, accountability seems to demand a single agency that can be held responsible for financial stability, not a committee--which would allow each member to point the finger of guilt at the others. ${ }^{24}$ So let's move rightward on the continuum.

Does it make sense to draw the line at point 2, separating financial stability, which is "macro-prudential," from the supervision of large SIFIs, which is generally called “micro-prudential?” I think not, and for a simple reason: It is mainly the actions and balance sheets of SIFIs that can, and occasionally do, imperil financial stability. And when things go awry, changes in the SIFIs' balance sheets, managements, riskmanagement systems, and the like will almost certainly be major elements of the cure. Indeed, this proposition comes close to being tautological. It is difficult to imagine systemic risk arising if every SIFI is operating safely and soundly. Conversely, the failure or near-failure of even a single SIFI might be enough to trigger a systemic crisis. Finally, because SIFIs are large, highly visible, and politically connected, we want their regulator to be fiercely independent of politics. Each of these considerations points straight to the Federal Reserve.

What about the next break point on the continuum, point 3, between supervision of SIFIs and supervision of smaller banks (and nonbanks)? Drawing the line there makes eminent sense because economies of scope are mostly absent. Supervising a \$100 million

\footnotetext{
${ }^{23}$ Indeed, central banks were working on financial stability long before any of them had any notions about monetary policy.

${ }^{24}$ This attitude is reflected in both the Treasury White Paper (U.S. Treasury 2009) and the House financial reform bill. But Senator Dodd's draft proposal takes the opposite position by elevating the FSOC over the Fed.
} 
community bank has little or nothing in common with supervising a complex $\$ 2$ trillion diversified SIFI. Their balance sheets bear practically no resemblance to one another. ${ }^{25}$ Their risk profiles are starkly different, as are their legal and management structures. SIFIs are likely to be global, while small banks are almost certain to be local. And so on and on. Besides, small banks do not pose systemic risks unless thousands of them make the same mistakes at the same time (e.g., as in the S\&L crisis of the 1980s).

Thus, in the U.S. context, it seems sensible to assign to the Fed responsibilities for (a) monetary policy, (b) systemic risk, and (c) supervising SIFIs - which might mean the largest 15-25 financial institutions, regardless of whether they have a bank charter. Adding (c) would, of course, expand the Fed's current authority. ${ }^{26}$ But other agencies could supervise the thousands of smaller banks, including the ones now supervised by the Fed, plus all the smaller broker/dealers and other financial institutions.

One technical but important issue remains: What, if anything, should be done about the once-obscure but now-famous Section 13.3 of the Federal Reserve Act-which has been invoked to justify most of the Fed's extraordinary interventions? The text of the law is worth quoting:

In unusual and exigent circumstances, the Board of Governors of the Federal Reserve System, by the affirmative vote of not less than five members, may authorize any Federal reserve bank, during such periods as the said board may determine, ... to discount for any individual, partnership, or corporation, notes, drafts, and bills of exchange when such notes, drafts, and bills of exchange are indorsed or otherwise secured to the satisfaction of the Federal Reserve bank.

In short, it says that, in an emergency, the Fed can lend to anyone and is the sole judge of whether the collateral is good.

\footnotetext{
${ }^{25}$ See, for example, Allen Berger et al. 1995. This study is a bit old, but the case, if anything, is far stronger now.

${ }^{26}$ But not by as much as might be thought. Under Gramm-Leach-Bliley, the Fed is already the umbrella supervisor of all financial holding companies.
} 
In a system of government founded on checks and balances, Section 13.3 is a remarkable, perhaps even breathtaking, grant of authority—especially since the powers are granted to unelected officials. It seems to me that 13.3 should be amended to require two things: sign-off by the Secretary of the Treasury, acting as the President's agent; and prompt reporting and explanation to the banking committees of both houses of Congress, probably under a confidentiality restriction for a period of time.

\section{Bank Supervision and Regulation}

Should the central bank also be a bank supervisor and regulator, or should those tasks be assigned to a separate agency, as is done in the U.K. and elsewhere? I have just argued that the Fed should supervise all the SIFIs. But what about the thousands of other banks and nonbank financial institutions in the United States? There the case for supervision by the central bank is far weaker.

Two main issues are relevant to deciding whether or not the central bank should also be a safety and soundness supervisor. One has been discussed already: economies of scope. The other has not yet been broached: possible conflicts of interest.

Given what has been said already, I can treat economies of scope briefly: Complementarities between monetary policy and bank supervision are probably strong when it comes to SIFIs but weak when it comes to small institutions. So a reconfigured Fed should probably gain new supervisory authority over SIFIs, regardless of whether they are (technically) banks, but lose its current supervisory authority over the 800-900 small state member banks. On mostly the same grounds, the Fed should probably also relinquish its responsibilities for enforcing the many consumer protection laws--as proposed in both the Treasury White Paper and the House version of financial reform 
legislation--and perhaps for the Community Reinvestment Act (CRA) as well. On balance, the Fed might wind up a smaller organization, not a larger one, as a result of this realignment of duties.

But what about the conflict-of-interest issue? It is not difficult to imagine banking institutions—-large and small—getting into trouble, and therefore meriting supervisory discipline, at a time when the macroeconomy is weak. If the central bank were also the safety and soundness supervisor, it would find itself pulled in two conflicting directions. Its supervisory role would tell it to discipline the wayward banks, which might well reduce overall bank lending. But its monetary policy role would suggest regulatory forbearance because the economy needs more lending. The result could easily be lax supervision just when banks are least safe and sound.

Or so the argument goes. But is it correct? Consider what might happen when supervisory authority and monetary policy are placed in different hands. In that case, the independent bank supervisor would be unlikely to take macroeconomic considerations into account. So it might crack down hard on the banks, thus limiting lending, just when the economy needs more credit. Maybe that's not the outcome society wants. ${ }^{27}$ Maybe it is more appropriate for supervisory discipline to be tempered by macroeconomic concerns. That is certainly the philosophy behind the Bank of Spain’s heavily praised system of "dynamic provisioning" for loan losses and behind current efforts to make regulatory capital requirements less procyclical. So what some people see as a worrisome conflict of interest between bank supervision and monetary policy might be viewed instead as the rational balancing of two competing objectives. If so, shouldn't a single

\footnotetext{
${ }^{27}$ For example, both in 1990-1992 and now, many critics have claimed that over-zealous regulators were/are limiting bank lending when it was/is most needed.
} 
agency do the balancing? And who can balance those competing objectives better than the central bank?

Once again, distinguishing between small banks and large banks may successfully square the circle. Even very stern (or very lax) safety and soundness discipline applied to, say, a few hundred small banks will have negligible macroeconomic consequences. But large expansions or contractions of credit by a few industry giants are almost certain to have macroeconomic consequences. So it makes sense to have the central bank supervise the SIFIs while leaving the rest to other agencies.

Finally, notice that making the Fed both the systemic risk regulator and the supervisor of SIFIs would make the central bank a larger and more powerful institution. Yet some people have argued, with some cogency, that the Fed has too much unchecked power already. My approach to this conundrum was mentioned earlier: We can take away the Fed's responsibilities for consumer protection, for supervising small banks, and for enforcing the CRA. Those three changes would reduce the Fed's range, influence, and certainly its headcount.

\section{Summing Up}

It is not just uncontroversial, but probably banal, to assert that the central bank is and should be the country's only lender of last resort and its sole (and independent) monetary policy authority. What seems to have been less noticed is that several related job assignments follow logically from that assertion. Most important, the central bank should be the systemic risk regulator because preserving financial stability is (a) closely aligned with the objectives of monetary policy and (b) likely to require LOLR powers. 
Conversely, however, some of the other roles the Federal Reserve has acquired over the years—-such as in consumer protection, CRA, and the supervision of certain small banks —are, at best, peripheral to its core mission and, at worst, "weak sisters” whose status within the central bank will always be dwarfed by monetary policy. Certainly these tasks do not require much in the way of LOLR powers. A rationalization of duties along the lines suggested here would probably leave the Fed a smaller but more focused agency.

Two main arguments have been raised against this realignment of duties. The most telling argument seems to be the potential conflict-of-interest problem just discussed: Safety and soundness considerations might sometime collide with monetary policy. While valid, that objection can easily be stood on its head: The central bank is probably best-positioned to balance the two competing objectives, rather than leaving them in the hands of two independent agencies. After all, we do not drive motor vehicles by assigning one person to the gas pedal and another to the brakes.

The other argument is political: Some people do not want the Fed to supervise SIFIs and/or serve as the systemic risk regulator because either role would push the central bank deeper into the realm of politics—which could, as a consequence, politicize monetary policy. There is a kernel of truth here. After all, systemic risk regulation will on occasion involve life-or-death decisions on specific, prominent, and politically-connected companies. With billions, if not trillions, of dollars at stake, such decisions will attract politicians like bees to honey.

My response to this argument is to grant the premise-yes, we want such decisions to be as apolitical as possible—-but then to remember the classic Henny Youngman 
question: “Relative to what?” In the American system of government, it is hard to imagine creating a new agency with anything approaching the Fed's degree of political independence — which is pretty much unheard of. If we want to minimize political influence on systemic risk issues, the Federal Reserve is the place to go. That's just exploiting the Fed’s comparative advantage.

\section{REFERENCES}

Acemoglu, Daron, Simon Johnson, Pablo Querubin, and James A. Robinson. 2008. "When Does Policy Reform Work? The Case of Central Bank Independence.” Brookings Papers on Economic Activity, 1: 351-417.

Berger, Allen N., Anil K. Kashyap, and Joseph M. Scalise. 1995. “The Transformation of the U.S. Banking Industry: What a Long, Strange Trip It’s Been.” Brookings Papers on Economic Activity, 2: 55-218.

Bernanke, Ben S. 2002. “Asset-Price ‘Bubbles’ and Monetary Policy.” Remarks before the New York Chapter of the National Association for Business Economics, New York, NY, October 15. http://www.federalreserve.gov/BoardDocs/Speeches/2002/20021015/default.htm. Bernanke, Ben S. 2009. “The right reform for the Fed.” The Washington Post, November 29. http://www.washingtonpost.com/wpdyn/content/article/2009/11/27/AR2009112702322_pf.html.

Bernanke, Ben S. 2010. “Monetary Policy and the Housing Bubble.” Remarks at the American Economic Association meetings, Atlanta, GA, January 3. 
Blinder, Alan S. 2000. “Central-Bank Credibility: Why Do We Care? How Do We Build It?” American Economic Review, 90 (5, December): 1421-1431.

Blinder, Alan S. 2004. The Quiet Revolution: Central Banking Goes Modern. New Haven, CT: Yale University Press.

Blinder, Alan S. 2006. "Monetary policy today: sixteen questions and about twelve answers." In Central banks in the $21^{\text {st }}$ century, ed. Santiago Fernández de Lis and Fernando Restoy, 31-71. Madrid, Spain: Banco de España.

Blinder, Alan S. 2008. “Two Bubbles, Two Paths.” The New York Times, June 15. http://www.nytimes.com/2008/06/15/business/15view.html.

Blinder, Alan S., and Ricardo Reis. 2005. “Understanding the Greenspan standard.” In The Greenspan Era: Lessons for the Future (proceedings of the 2005 Jackson Hole conference), 11-96. Kansas City, MO: Federal Reserve Bank of Kansas City.

Greenspan, Alan. 2002. “Opening remarks.” In Rethinking Stabilization Policy (proceedings of the 2002 Jackson Hole conference), 1-10. Kansas City, MO: Federal Reserve Bank of Kansas City.

Greider, William. 1987. Secrets of the Temple: How the Federal Reserve Runs the Country. New York, NY: Simon and Schuster.

Mishkin, Frederic S. 2008. “How Should We Respond to Asset Price Bubbles?” Speech at the Wharton Financial Institutions Center and Oliver Wyman Institute’s Annual Financial Risk Roundtable, Philadelphia, PA, May 15. http://www.federalreserve.gov/newsevents/speech/mishkin20080515a.htm. Paul, Ron. 2009. End the Fed. New York, NY: Grand Central Publishing. 
Rudebusch, Glenn D. 2002. “Term structure evidence on interest rate smoothing and monetary policy inertia.” Journal of Monetary Economics, 49(6, September): 11611187.

Svensson, Lars E.O. 1999. "How Should Monetary Policy Be Conducted in an Era of Price Stability?” In New Challenges for Monetary Policy (proceedings of the 1999 Jackson Hole conference), 195-259. Kansas City, MO: Federal Reserve Bank of Kansas City.

U.S. Department of the Treasury. 2009. Financial Regulatory Reform: A New Foundation, June 17. Washington, D.C.: U.S. Department of the Treasury. http://www.financialstability.gov/docs/regs/FinalReport_web.pdf. 